\title{
Increased RNA Synthesis in Nuclei Isolated from Rat Liver Tissue Slices Incubated with Cyclic Adenosine 3', 5'-Monophosphate or Glucagon'
}

\author{
LINDA A. DOKAS, MITCHELL D. BOTNEY, ${ }^{2}$ AND LEWIS J. KLEINSMITH
}

\author{
Department of Zoology, The University of Michigan, Ann Arbor, Michigan 48104 \\ Received September 3, 1973
}

\begin{abstract}
Incubation of rat liver tissue slices with cyclic adenosine $3^{\prime}, 5^{\prime}$-monophosphate (cyclie AMP) for $30 \mathrm{~min}$ results in a dose-dependent increase in $\mathrm{RNA}$ synthesizing capacity of nuclei prepared from these slices, with a doubling of synthetic rate observed at $10^{-7} \mathrm{M}$ cyclic AMP. The cyclic AMP effect is observed when RNA polymerase activity is measured either in the presence of $\mathrm{Mg}^{2+}$ and low ionic strength, or $\mathrm{Mn}^{2+}$ and high ionic strength. Experiments employing saturating amounts of exogenous bacterial RNA polymerase suggest that the cyclic AMP-induced stimulation occurs prinarily at the level of template activity. Other cyclic nucleotides tested in the same manner are ineffective in stimulating RNA synthesis by tissue slice nuclei. In addition to cyclic AMP, adenosine 5'-monophosphate (5'-AMP) consistently produced small increases in nuclear RNA synthesis although never of the magnitude seen with the cyclic nucleotide.

An increased capacity for RNA synthesis is also seen in nuclei isolated from liver slices incubated with glucagon at concentrations from $0.5 \mu \mathrm{g} / \mathrm{ml}$ to $50 \mu \mathrm{g} / \mathrm{ml}$. A maximal stimulation of approximately twofold occurs at a glucagon concentration of 1.0 $\mu \mathrm{g} / \mathrm{ml}$. Liver slices incubated with optimal concentrations of cyclic AMP and glucagon simultaneously show that the effects of the two agents on RNA synthesis are not additive.

The results indicate that cyclic AMP at physiological concentrations can stimulate RNA synthetic capacity in vitro, and that the effect mimics a similar response to glucagon. Since it is known that glucagon causes an increase in liver concentrations of cyclic AMP and a subsequent induction of some liver enzymes, it is suggested that cyclic AMP-mediated control of RNA synthesis may be involved in such regulation.
\end{abstract}

Cyclic adenosine $3^{\prime}, 5^{\prime}$-monophosphate (cyclic AMP) ${ }^{3}$ is now known to be an im-

1 This work was supported by Grant GB-23921 from the National Science Foundation and Institutional Grant IN-40L from the American Cancer Society.

${ }^{2}$ Recipient of an Flsa U. Pardee Student Fellowship.

${ }^{3}$ Abbreviations used: cyclic AMP, or cAMP, adenosine $3^{\prime}, 5^{\prime}$-monophosphate; cyclic GMP, guanosine $3^{\prime}, 5^{\prime}$-monophosphate; cyclic UMP, uridine 3',5'-monophosphate; cyclic CMP, cytidine $3^{\prime}, 5^{\prime}$-monophosphate; KRP, 0.14 м NaCl, $5 \mathrm{~mm}$ $\mathrm{KCl}, 2.3 \mathrm{~mm} \mathrm{CaCl}_{2}, 1.3 \mathrm{~mm} \mathrm{MgSO}_{4}, 0.01 \mathrm{M}$ $\mathrm{Na}_{2} \mathrm{HPO}_{4}$, pH 7.4; TMS, 0.01 м Tris-HCl, $4 \mathrm{~mm}$ portant factor involved in the control of RNA synthesis in bacterial systems (1). Recent evidence has led to the proposal that a cyclic AMP-protein complex binds to $E$. coli DNA and serves as a positive signal for the initiation of transcription of the genes for a number of inducible cnzymes (2). Since ryclir AMP is known to mediate the effects of a large number of hormones in higher organisms (3), it seems of interest to determine whether any of

$\mathrm{MgCl}_{2}, 0.25$ м sucrose, $\mathrm{pH} 8.3 ;$ TCS, 0.01 м Tris$\mathrm{HCl}, 3 \mathrm{mM} \mathrm{CaCl}_{2}, 0.25$ м suerose, $\mathrm{pH} 8.3$. 
these responses also involve the control of RNA synthesis by this eyclic nucleotide. Recently some evidence has begun to accumulate which supports the possibility that cyclic AMP does play a role in controlling gene transcription in rukaryotic cedls. For example, it has been shown in a number of different systems that cyclic AMIP causes an increase in the rate of incorporation of radioactive precursors into RNA (4-15). One system which has been extensively studied and serves as a good model in this regard is the stimulation of mammalian liver by glucagon, a hormone whose actions are known to be mediated at least in part by cyclic AMP (3). Administration of glucagon or cyclic AIIP has been shown to cause the induction of a specific set of enzymes in rat liver (16), and inhibition of RNA synthesis by actinomycin I) blocks such effects on at least one enzyme (17). Furthermore, Langan (18, 19) has observed that phosphorylation of liver $f_{1}$ histone is stimulated by both glucagon and evclic AMP, a finding which has led him to suggest that this histone modification may lead to a specific stimulation of transeription of the genes coding for some glucagon-inducible enzymes.

If Langan's hypothesis is correct, then cyclic $\Lambda$ MP should eause an increase in the rate of RNA synthesis in rat liver, although the magnitude of this effect might not be very great due to the small number of enzymes whose synthesis is induced by this nucleotide. Consistent with this prediction, positive effects of cyclic AMP on RNA synthesis in rat liver have been observed both by injecting cyclic AMP in vivo (10) and by incubating coll-free systems with cyclic AMP in vitro $(9,12)$. Unfortunately, the in vivo experiments are complieated by the possibilities of secondary effects when injecting whole animals with crclic AMIP, while most of the in vitro experiments with isolated nuclei required relatively high concentrations of cyclic AMIP to produce effects.

In order to try to overcome these difficultios, we have chosen to study RNA synthesis in nuclei obtained from liver slices which have been incubated with cyclic AXIP or glucagon. The present studies show that in such a system low concentrations of both cyclic AMP and glucagon produce significant increases in the ability of nuclei to synthesize RNA. Since these two substances do not give additive effects when administered together, it is suggested that the stimulation of RNA sinthesis by glucagon is mediated by its elevation of eyclic AMIP levels and that the resulting effects on RNA synthesis may be involved in the mechanism of action of this peptide hormone.

\section{MATERIALS ANI) METHODS}

Preparation and incubation of liver slices. Adult male Sprague-1)awley rats were fasted $18-20 \mathrm{hr}$ prior to the start of each experiment. The rats were sacrificed by decapitation and the livers perfused with $15 \mathrm{ml}$ of ice-cold $0.14 \mathrm{M} \mathrm{NaCl}$. Liver slices were prepared at $4^{\circ} \mathrm{C}$ with a Stadie-Riggs microtome (Arthur Thomas) and placed in $50 \mathrm{ml}$ of Krebs Ringer phosphate (KRP) buffer (0.14 M $\mathrm{NaCl}, 5 \mathrm{mu} \mathrm{KCl}, 2.3 \mathrm{~mm} \mathrm{CaCl}, 1.3 \mathrm{~mm} \mathrm{MgSO}_{4}$, $0.01 \mathrm{M} \mathrm{Na}_{2} \mathrm{HPO}_{4}, \mathrm{pH} 7.1$ ). Just before incubation, control slices were transferred into $50 \mathrm{ml}$ of fresh KRP. Experimental slices were placed into $50 \mathrm{ml}$ KIR containing various concentrations of cyclic nucleotides and/or glucagon. Slices were incubated at $37^{\circ} \mathrm{C}$ for $30 \mathrm{~min}$ with constant shaking. At the end of this period, the supermat ant medium was decanted and the $\mathrm{pH}$ read.

Isolation of mulei. All operations were carried out at $4^{\circ} \mathrm{C}$. Fach $5 \mathrm{~g}$ of liver (slices or fresh) was homogenized with a Dounce homogenizer (4 strokes with loose pestle and 3 strokes with tight pestle) in $3 \mathrm{vol}$ of $0.32 \mathrm{~m}$ sucrose $/ 3 \mathrm{~mm} \mathrm{MgCl}$. The homogenates were spun at $1,000 g$ for $15 \mathrm{~min}$, and the resulting pellets suspended in $40 \mathrm{ml}$ of $2.4 \mathrm{M}$ sucrose $/ 1 \mathrm{~mm} \mathrm{MgCl}_{2}$ with a Sorvall Omnimixer. The preparations were centrifuged at $105,000 \mathrm{~g}$ for $1 \mathrm{hr}$, the nuclear pellets resuspended and washed two times in TMs $(0.01$ м Tris- $\mathrm{HCl}, 0.25 \mathrm{~m}$ sucrose, $4 \mathrm{~mm} \mathrm{MgCl}_{2}, \mathrm{pH} 8.3$ ), and finally suspended in 2 vol of TMS.

Heasurements of RNA synthesis by isolaled melei. Assays for magnesium-activated RNA synthesis were performed by incubating $0.1 \mathrm{ml}$ of nuclei $(400-600 \mu \mathrm{g}$ DNA) in a final volume of 0.5 $\mathrm{ml}$ of reaction medium containing $8 \mathrm{~mm}$. Tris- $\mathrm{HCl}$, $\mathrm{pH} 8.3,0.2$ м sucrose, 4 mm $\mathrm{MgCl}_{2}, 0.2 \mu \mathrm{Ci}\left[8-{ }^{14} \mathrm{C}\right]-$ ATP (30 mCi/mmole), and $1.8 \mathrm{mu}$ each CTP, GTP, and UTP. For measurements of manganeseactivated RNA synthesis, nuclei were washed in TCS (0.01 м Tris- $\mathrm{HCl}, 3$ mм $\mathrm{CaCl}_{2}, 0.25$ м sucrose, pH 8.3) instead of TMs, and $0.1-\mathrm{ml}$ aliquots of nuclear suspension were then incubated in a final volume of $0.5 \mathrm{ml}$ of reaction medium containing 8 
mu Tris-HCl, $\mathrm{pH}$ 8.3, ().2 м sucrose, $1.6 \mathrm{~mm} \mathrm{CaCl}_{2}$, $0.6 \mathrm{~mm} \mathrm{MnCl}_{2}, 40$ пाм $\left(\mathrm{NH}_{4}\right)_{2} \mathrm{SO}_{4}, 0.2 \mu \mathrm{Ci}\left[8-{ }^{14} \mathrm{C}\right]-$ ATP (30 mCi/mmole), and $1.8 \mathrm{~mm}$ each CTP, GTP, and UTP. In both cases, 0.1-ml samples were taken at 1,3 , and $5 \mathrm{~min}$, and incorporation of radioactivity into acid-insoluble material determined as described elsewhere (10).

Nuclear DNA concentrations were determined by a modified indole procedure (20). Insulin-free glucagon $(0.0000025 \%$; $0.6 \mu \mathrm{U} / \mathrm{mg})$ was kindly supplied by David Brennan of lili Lilly Co., Indianapolis, IN.

\section{R. WSULTS}

RVA symthesis in muclei isolated from liver slices. It is known that rat liver nuclei carry on RNA synthesis in vitro and that transcription of chromatin prepared from rat liver nuclei results in the production of an RNA complement similar to that transcribed in vivo (21-23). However, because of the time needed to prepare and incubate liver slices, and to isolate nuclei from these slices, it seemed necessary to detrormine at the outset whother RNA synthesis in nuclei isolated from such slices occurred at a rate comparable to that of nuclei prepared directly from rat liver.

As is shown in Fig. 1, nuclei isolated from rat liver slices which had been incubated for $1 \mathrm{hr}$ prior to nuclear isolation oxhibit a rate of RNA synthesis comparable to that of nuclei isolated directly from liver. Therefore, it is assumed that the nuclei used in this sed of experiments are not only viable, but are also comparable to standard rat liver nuclei in regard to both rate of nucleotide incorporation and total amount of RNA synthesized.

Fiffects of mucleotides on RVA synthesis. When rat liver slices are incubated for 30 min in the presence of varying concentrations of cyclic A.IP, nuclei isolated from these slices are found to exhibit an increased rate of RNA synthesis (Fig. 2). The optimal effect is observed at a cyclic AlIP' concentration of $10^{-7}$.I, whore a doubling of the rate of RNA synthesis oceurs. Some stimulatory effeet can be observed at cyclic AMP concentrations as low as $10^{-9} \mathrm{M}$, and in the presence of 1 m.s theophylline optimal stimulation was found to occur with cyclic AMI' concentrations as low as $10^{-\infty} \mathrm{M}$.

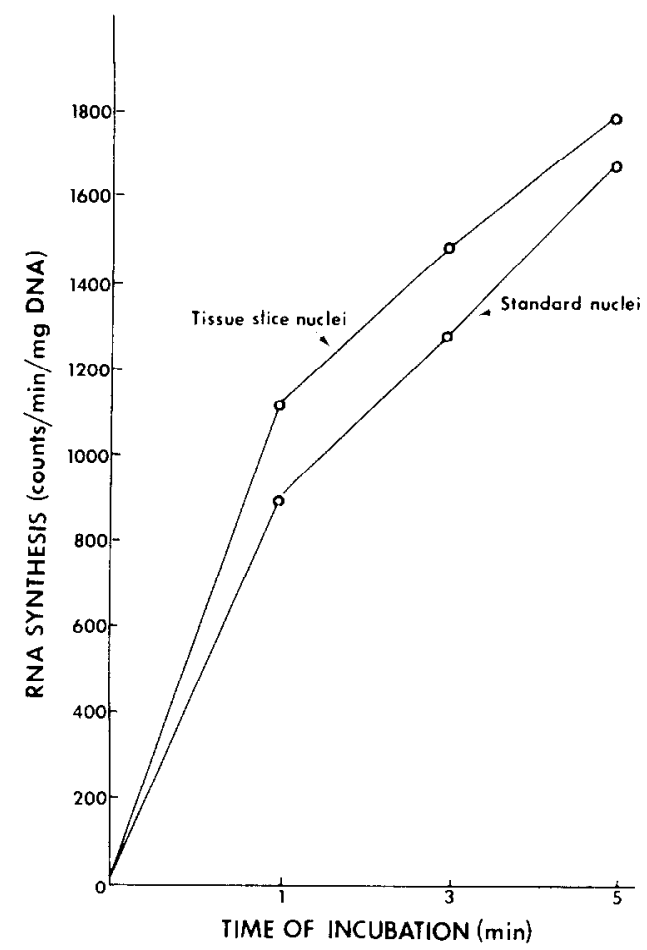

FIa. 1. Comparison of rates of RNA synthesis in nuclei obtained from rat liver slices versus nuclei obtained directly from fresh liver ("standard nuclei"). Liver slices were prepared as described in the text and incubated for $1 \mathrm{hr}$ at $37^{\circ} \mathrm{C}$ prior to isolation of nuclei. RNA synthesis was measured in the magnesium-containing medium. Wach point is the average of 5 samples of $0.1 \mathrm{ml}$ each; standard deviations for each set of points show no significant differences between standard and slice nuclei.

In order to determine whether the observed stimulation of RNA synthesis is specific for cyclic AMIP, we have tested the effects of a varicty of other nucleotides in this system. Incubation of liver slices with 5'-A.MP causes a small, but reproducible, stimulation of RNA synthesis (Fig. 3). This effect is never near the magnitude of that seen with cyclic AMIP, although concontrations as high as $10^{-3}$. I have been tested. No other $\tilde{5}^{\prime}$ - or cyclic nucleotides tosted in this system have been found to produce any significant alterations of RNA synthesis (Fig. 4).

Since nuclear RNA synthesis is now known to be catalyzed by at least two distinet RXA polymerase activition, one activated 


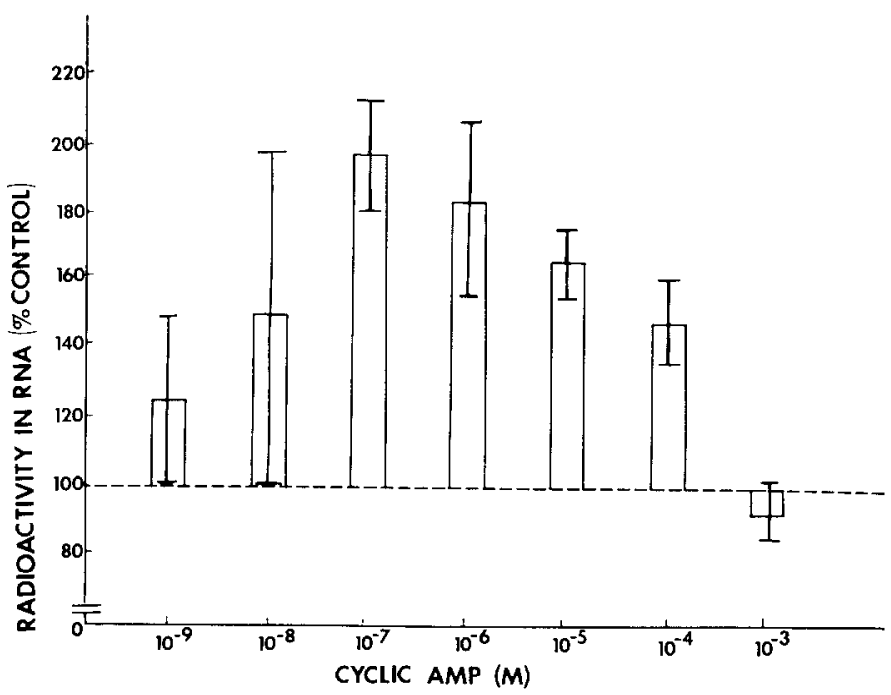

FIg. 2. Effects of incubating rat liver slices with varying concentrations of cyclic AMP on rates of RNA synthesis in nuclei isolated from these slices. Cyclic AMP was included during a 30-min incubation, after which nuclei were isolated and IRNA synthesis measured in the magnesium-containing medium during a 3-min incubation. The data represent averages obtained from at least two, and in some cases, up to five experiments. The vertical lines are standard deviations. The eontrol value in this experiment represents $727 \mathrm{cpm} / \mathrm{mg}$ I) NA.

by magnesium and one by manganese (24-26), we compared the affects of cyclic ANIP on RNA synthesis under each of these conditions. As is shown in lig. 5, both magnesium- and manganesr-activated RNA synthesis are stimulated by cyclic: AMP.

One common way to determine whether an observed stimulation of RNA synthesis is caused via an effect on RNA polymerase or chromatin template activity is to incubate with saturating amounts of exogenous bacterial RNA polymerase. As is seen from the data in Table I, crelic AMP induces a comparable perecntage increase in $\mathrm{RNA}$ synthesis in nuclei incubated with exogenous. RNA polymerase. These results suggest that the effect of the cyclic nuclootide may be at the level of chromatin template activity rather than a stimulation of endogenous RXA polymorase, although alternative explanations are also possible. Effects of glucagon and epinephrine on $R N A$ synthesis. When rat liver tissue sliecs are incubated in the presenee of varying concentrations of glucagon, nuclei isolated from these sliees are also found to exhibit an increased rate of RNA synthesis (Fig. 6). Again the response is found to be concentration dependent, with near optimal effects being observed with hormone concentrations as low as $1.0 \mu \mathrm{g} / \mathrm{ml}$. It is of interest to note that in the case of both cyclic AMIP and glueagon, the maximum increases in RNA synthesis seen are of the same magnitude, approximately a doubling of control values. In order to rulo out the possibility that the stimulation of RNA synthesis seen with glucagon was caused by insulin contamination, "insulin-free" glucagon $(<0.0000025 \%$ insulin) was obtained from Eli Lilly Co. and tested in this system. Under such conditions, a similar stimulation of RNA synthesis was observed.

Since glueagon is known to clevate cyclic AMP levels in rat liver (3), it is possible that the stimulation of RNA synthesis seen with glueagon is in fact mediated by this increase in crelic AXII', which we have already seen can stimulate RNA svnthesis. On the other hand, it is conceivable that glueagon is stimulating $\mathrm{RNA}$ synthesis via a mochanism independent from cyelic AMIP. It is rasy to distinguish betwoen these 


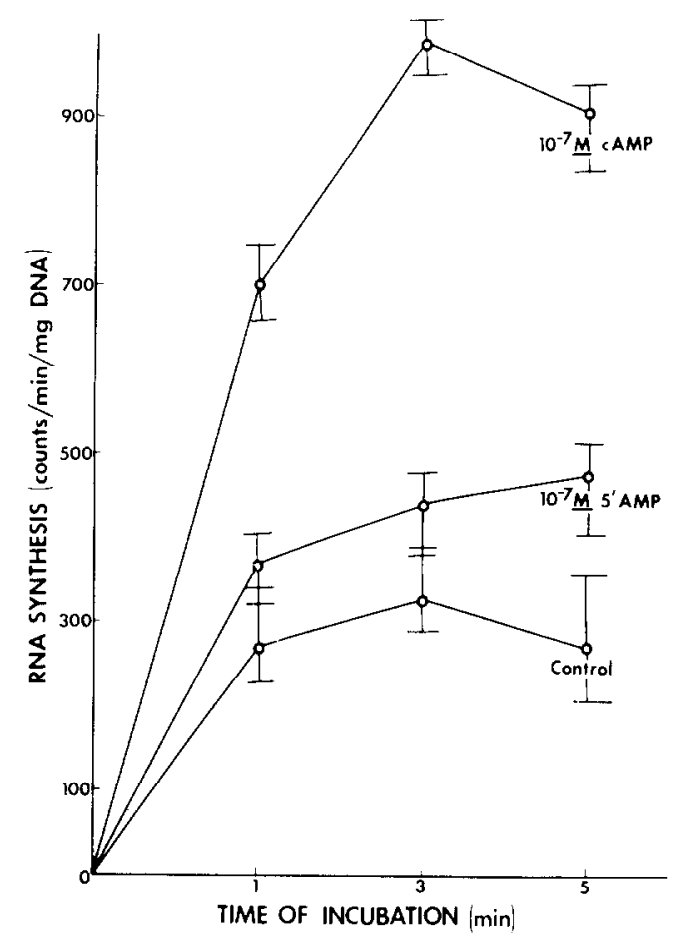

FIG. 3. Comparison of rates of RNA synthesis in nuclei obtained from rat liver slices incubated with cyclic AMP or 5'-AMP. Slices were incubated for 30 min with $10^{-7}$ м nucleotide, after which nuclei were isolated and RNA synthesis measured in the magnesium-containing medium. A small, but reproducible stimulation occurs with $5^{\prime}$-AMP, although the magnitude of the effect never approaches that seen with cyclic AMP. Vertical lines are standard deviations.

possibilities experimentally, since, if glucagon is acting on RNA synthesis independently of cyclic AMP, the effects of these two agents should be additive. As is shown in Fig. 7, simultaneous addition of glucagon and cyclic AMP to tissue slice incubations stimulates RNA synthesis in isolated nuclei to no greater extent than the presence of either agent alone.

If glucagon is stimulating RNA synthesis via a cyclic AMP-mediated mechanism, then one might expect other agents which elevate cyclic AMP levels to also enhance RNA synthesis in this system. Consistent with this prediction, we found that epincphrine at a concentration of $1.0 \mu \mathrm{g} / \mathrm{ml}$ caused a $60 \%$ stimulation of the rate of RNA synthesis.
TABLE I

EFFets of Exoglinous RNA Polymerasli on Cyclic AMP-Induclid Stimulation of RNA ÂYNTHESIS ${ }^{a}$

\begin{tabular}{|c|c|c|c|}
\hline \multirow[t]{2}{*}{ Condition } & \multicolumn{2}{|c|}{$\begin{array}{l}\text { Radioactivity in } \\
\text { RNA (cpm/mg } \\
\text { DNA) }\end{array}$} & \multirow[t]{2}{*}{$\begin{array}{l}\text { Stimula- } \\
\text { tion }(F / y \\
\text { control }\end{array}$} \\
\hline & Control & $\begin{array}{c}+ \text { cyclic } \\
\text { AMP }\end{array}$ & \\
\hline A. $\mathrm{Mg}^{2+}$-containing assay & & & \\
\hline Complete system & 1,296 & 2,460 & 190 \\
\hline $\begin{array}{l}+E \text {. coli RNA polym- } \\
\text { erase }\end{array}$ & 2,592 & 4,780 & 183 \\
\hline B. $\mathrm{Mn}^{2+}$-containing assay & & & \\
\hline Complete system & 6,750 & 8,775 & 130 \\
\hline $\begin{array}{l}+E . \text { coli RNA polym- } \\
\text { erase }\end{array}$ & 11,400 & 22,100 & 194 \\
\hline
\end{tabular}

a Nuclei were prepared from rat liver slices incubated for $30 \mathrm{~min}$ with or without $10^{-6} \mathrm{M}$ cyclic AMP as described in Methods. Assay for RNA synthesis was done by labeling for 3 min is either magnesium- or manganese-containing media. In cases where the effects of exogenous RNA polymerase were tested, 12 units (a saturating amount) of $E$. coli RNA polymerase were added.

\section{DISCUSSION}

Although firm evidence exists that cyclic AMP mediates the action of glucagon in rat liver, little is known about the mechanism by which cyclic AMIP activates the synthesis of glucagon-inducible enzymes. The present experiments lend support to the possibility that at least part of the effects of cyclic AMP are mediated via effects on gene transcription. We have found that incubation of rat liver slices with concentrations of eyclic AMP in the physiological range can cause dramatic increases in the capacity for RNA synthesis in nuclei isolated from these slices. Although others have been able to observe such effects in liver slices only with the dibutyryl derivative of cyclic A.MP (12), they did not measure RNA synthesis directly in isolated nuclei as was done in the present studics. The virtual absence of any comparable effects for a wide range of other nucleotides tested in our system suggests that the effect is highly specific for cyclic A.IP. The only other nucleotide which causes any significant mhancement of 
RNA synthesis is $5^{\prime}-A M P$, and its effect is much less dramatic than that observed with eyclic AMIP. Since it is known that 5 -AMP ean artivate adenyl crolase in brain tissue (297), it is possible that even the offects of $5^{\prime}$-A.MP in our system are mediated via cyelic AMP.

It is of interest to note that coneentra-

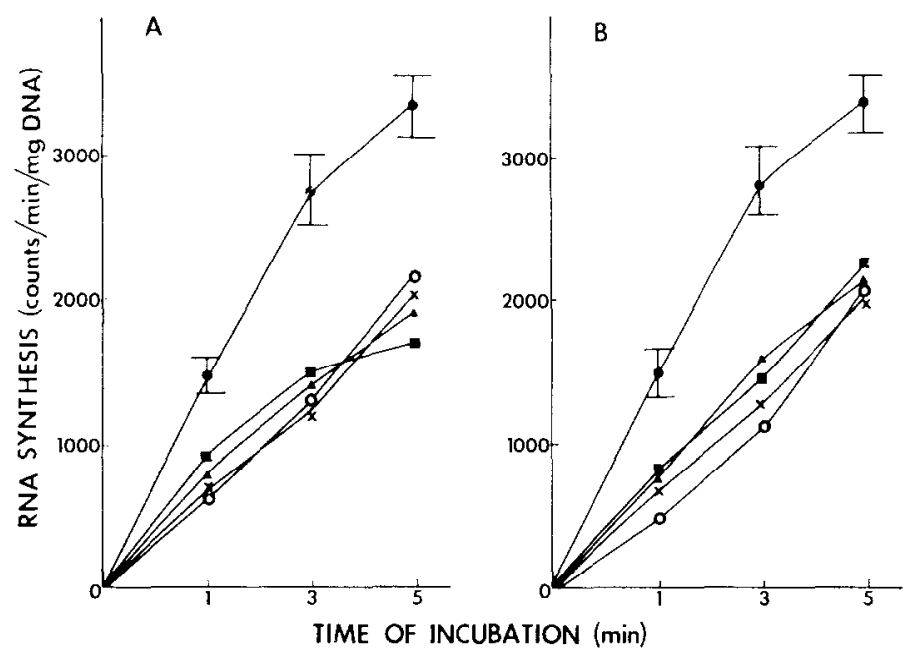

Frg. 4. Comparison of rates of RNA synthesis in muclei obtained from rat liver slices incubated with various nucleotides at $10^{-6} \mathrm{M}$. Fxperiments were performed as deseribed

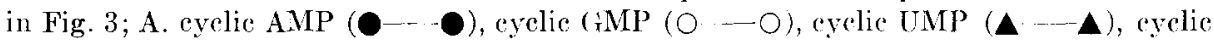

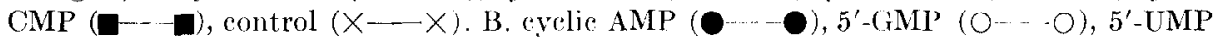
$(\mathbf{A}-\mathbf{A}), 5^{\prime}$-CMP $(\square-\square)$, control $(X--X)$. Note that of all these nucleotides tested, only cyclic AMP causes a significant stimulation of RNA synthesis. Vertical lines are standard deviations.

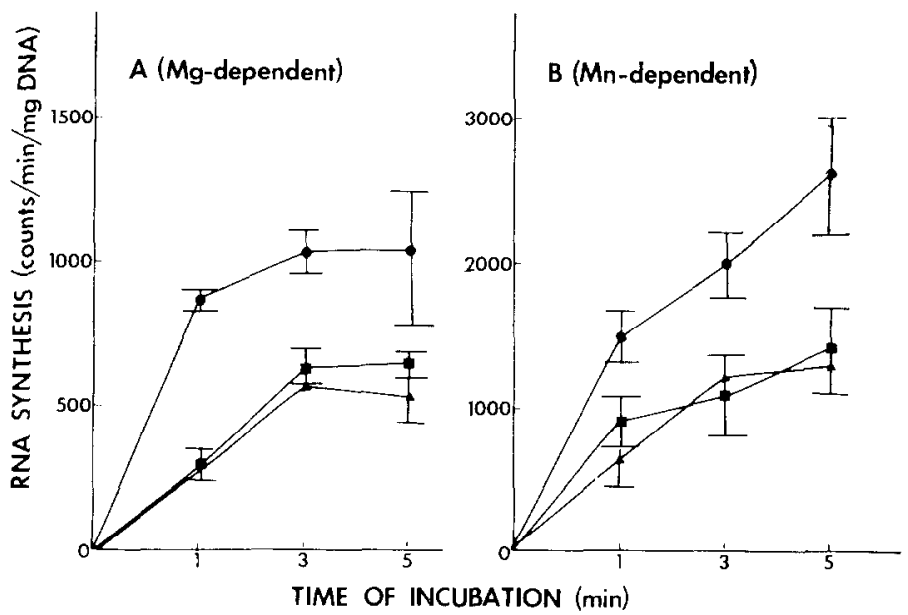

FIG. 5. Comparison of the effects of cyclic AMP on magnesium-and manganese-dependent RNA synthesis. Rat liver slices were incubated with cyclic AMP for 30 min, nuclei isolated, and their capacity for RNA synthesis measured in either magnesium- or manganese-containing media as described in the text. Fffects of $10^{-7} \mathrm{M}(-\mathrm{C})$ and $10^{-3} \mathrm{M}$ (A-D) cyclic AMP are compared to control values

a). Note that a concentration-dependent stimulation of both lypes of RNA syuthesis occurs. Vertical lines are standard deviations. 


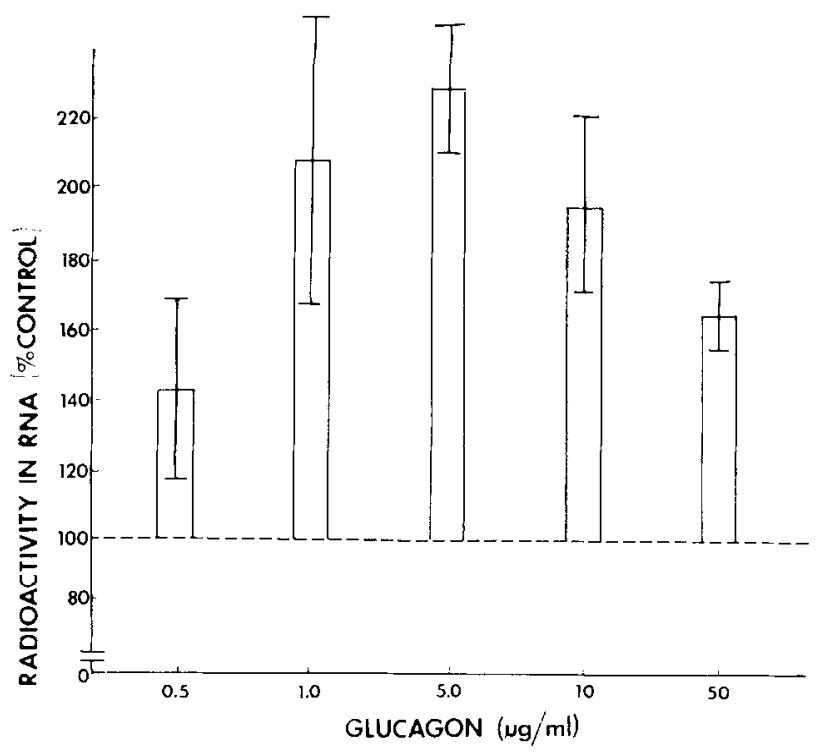

FIa. 6. Effects of incubating rat liver slices with varying concentrations of glucagon on rates of RNA synthesis in nuclei isolated from these slices. Glucagon was included during a 30 -min incubation, after which nuclei were isolated and RNA synthesis measured in the magnesium containing medium for $3 \mathrm{~min}$. The control value in this case represents 400 $\mathrm{cpm} / \mathrm{mg}$ DNA. Vertical lines are standard deviations.

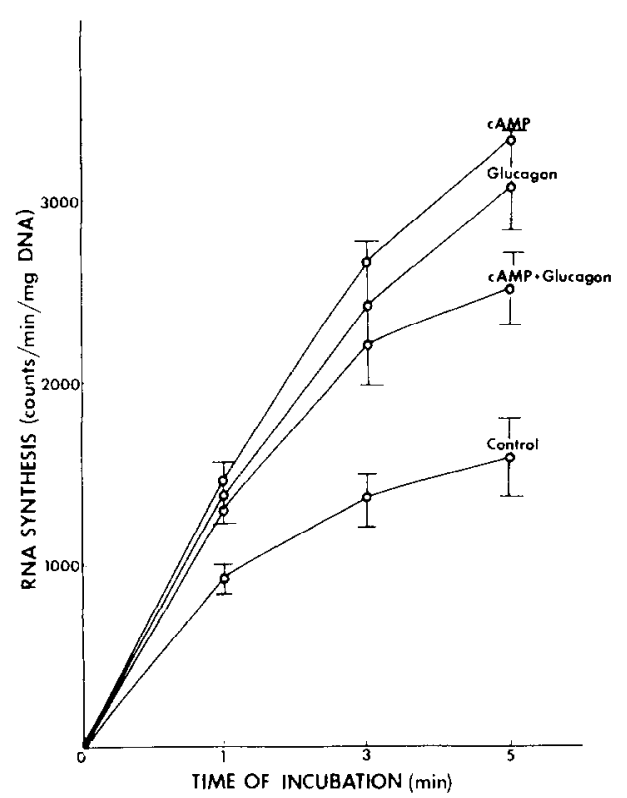

FIG. 7. Effects of cyclic AMP and glucagon on RNA synthesis. Rat liver slices were incubated for $30 \mathrm{~min}$ with $10^{-5}$ M eyclic AMP, $5.0 \mu \mathrm{g} / \mathrm{ml}$ glucagon, or both. Nuclei were isolated, and RNA synthesis was measured in the magnesium-containing medium. Note that the effects of cyclic AMP and glucagon are not additive. Vertical lines are standard deviations. tions of cyclic AMP higher than $10^{-6} \mathrm{M}$ in the slice incubation medium produce submaximal increases in nuclear RNA synthesis. It is a possibility that the intracellular concentrations of ryclie AMP generated by these high incubation dosages may activate some sort of a negative feedback system, i.e., high levels of cyclic AMP may activate phosphodiesterase activity (28) or some as yet unknown inhibitor of eyclic AMIP action. Little concrete evidence is available to explain how responses to cyclic AMP' are turned off, but data such as described here imply that regulation at this point may be as complex as activation of the entire system.

Several aspects of these experiments suggest that a physiologically relevant responso is being observed. In addition to the above-mentioned specificity of the offect for cyclic AMP and its cffectiveness at low concentrations, another significant observation in this regard is the fact that low levels of glucagon produce a stimulation of RNA synthosis similar to that seen with cyclic AMI and that optimal doses of glucagon and cyclic AMP in combination produce an effect no grrater than rither 
alone. Such data are eonsistent with the fact that cyclic AMIP is known to bo a mediator of glucagon action in vive and suggest the possibility that the mechanism of action of glucagon involves at least in part a cyclic AMP-modiated stimulation of RNA syuthesis. Glucagon has several actions in mammalian liver (3), but the one which secms most likely to involvo RNA synthesis is the induction of a series of enzymes. The fact that cyclic AMIP itsolf, when directly applied, can also induee the formation of these same rnzrmes $(16,17)$ further supports the possibility that a cyelic A.IP-induced activation of gene tianscription is involved in glueagon action. In support of this general idea, in at least. one case (1.5) cyclic AMP has been shown to stimulate synthesis of $R \times A$ rich in poly (A), which is thought to be a characteristic of messenger RNA.

This brings us to the question of pessible mechanisms which might explain how cyclic AMl' can activate gene transcription in this system. Langan (18, 19) has suggested that crelie AMI'-activated phosphorylation of $f_{1}$ histones causes a change in chromatin template activity, leading in turn to an activation of transeription of the genes coding for the glucagon-inducible enzymos. Such a model would predict only small increases in overall RNA synthesis following cyclic AMP administration, and yet the present data show that under optimal conditions a doubling of the rate of nuelear RNA synthesis ran be produced by exclic AMP. Such inereases are obviously beyond what would be needed to account for the sinthesis of those messenger RNAs coding for a small number of inducible enzymess.

Several possibilities can be considered which might aecount for such unexpretedly large increases in nuclear RNA synthesis. One obvious possibility is that the wnthesis of species of RNA other than the specific messages for the glucagon-inducible (nzymes are involved. Jost and Sahib (19) have shown that the synthesis of both preribosomal and heterodisperso nucleas RNAs are stimulated when isolated nucloi are incubated with dibutyry crelic A.MP. The present experiments show that both magnesium - and manganciseactivated RNA polymerase activities are increased by incubation of liver slices with eyclie AMP', a finding which is also consistent with the stimulation of sunthosis of ribosomal as well as nouribosomal RNA species. Another complication which is relevant when (oonsidering the mignitude of the observed stimulation of RNA synthesis is the wollestablished finding that only a small portion of the total amount of RXA sinthesized on chromatin evor loaves tho nucleus to bereme involved in the proeess of rytoplasmic protein sinthesis (29). Thus it is difficult to make any direct comparisons between the overall rate of muclear RNA synthesis and the amount of RNA which eventually funetions as rytoplasmic mossages for the synthesis of inducible onzymos.

Rorernt rvidences suggents several other possible mechanisms for the eyclic A.MPinduced stimulation of RNA synthesis, in addition to the previously mentioned model based on cyclic AMP-modiated stimulation of histone phosphorylation. For example, cyclic AMl' has reently been shown to stimulate the phespherylation of nonhistone: chromatin protrins in rat liver (30), and the existence of multiple nuclear protein kinases with differing substrate specificities and dependencises on cyclic AMP has bern demonstrated $(31,32)$. Thus, the possibility arises that ryclic AMP may have multiple reffects in both stimulating and inhibiting $(31,32)$ the phosphorylation of specific nonhistone proteins, and in view of the recent rvidenee suggesting a role of nonhistone chromatin proteins in the regulation of gerese transcription, such phosphorylation reactions may bo involved in regulating RNA sinthesis (33)-37). Another possible efferet of " $\mathrm{y}$ elie A.MP is dircetly on RNA polymerase itself, sinee there has beren some suggestion in the literature that a cyclic A.MP'stimulated phesphorylation of a bacterial RNA polymerase factor may aclivate the (nzyme for transcription (38). In this regard, how'ver, our data with exogenous RXA polymorase suggest that the primary affeet is not at the level of RNA polymorase activity. Finally, there is some evidenes: from aukaryotic cells for an effect of a cyclic A.YP protein complex 
directly at the level of the DNA template (12), analogous to the situation found in bacteria (2). Thus, a variety of possible mechanisms exist which might explain the effects of cyclic AMP on RNA synthesis. Indeed, it is quite possible that more than one type of mechanism might be at work.

The present experiments thus demonstrate that cyclic AMP can dramatically stimulate the ability of rat liver nuclei to synthesize RNA and suggest that such a mechanism is involved in the action of glucagon on this tissue. These results do not imply that all the actions of these agents are mediated at a transcriptional level, and indeed there is good evidence that eyclic AMIP also acts at the posttranscriptional level $(16,39,40)$. The present experiments make it clear, however, that any complete model of how this cyclic nucleotide acts in higher organisms must take into account the observed effects at the level of gene transcription.

\section{ACKNOWLED(TMENT}

We thank Sandra J. Beadle for preparation of the illustrations.

\section{REFERENCES}

1. Pastan, I., and Philain, R, (1970) Science 169,339 .

2. Nissley, P., Anderson, W. B., Gallo, M., Pastan, 1., and Phrlman, R. L. (1972) J. Biol. Chem. 247, 4264.

3. Robison, G. A., Butcher, R. W., AND Sutherland, E. W. (1971) Cyclie AMP, Academic Press, New York.

4. Wilson, B. D., AND Wright, R. L. (1970) Biochem. Biophys. Res. Commun. 41, 217.

5. Sharma, S. K., and Talwar, G. P. (1969) J. Biol. Chem. 245, 1513.

6. Adiga, P. R., Murthy, P. V. N., AND MCKenzi , J. M. (1971) Biochemistry 10, 702.

7. Pisarev, M. A., DeGroot, L. J., ANo Wilbur, F. J. (1970) Endocrinology 87, 339.

8. Macchia, V., and Varrone, S. (1971) Fed. Eur. Biochem. Soc, Letters 13, 342.

9. Jost, J. P., ANd SAHib, M. K. (1971) J. Biol. Chern. 246, 1623.

10. Dokas, L. A., And Kikinsmith, L. J. (1971) Science 172, 1237.

11. Salomon, D., and Mascarenhas, J. P. (1972). Biochem. Biophys. Res. Commun. 47, 134.

12. Varrone, A., Ambesi-Impiombato, F. S., AN1)
Macchi, V. (1972) Fed. Eur. Biochem. Soc. Letters 21, 99.

13. Nussporfir, (i. (4., ind Mizzocchi, G. (1972). Acla Endocrinol. 70, 81.

14. Averner, M. J., Brock, M. C., And Jost, J. P. (1972) I. Biol. Chem. 247, 413.

15. Rosenfeld, M. G., Abrass, I. B., Mendelsohn, J., Roos, B. A., Boone, R. F., and Garken, L. D. (1972) Pror. Nat. Acad. Sci. USA 69, 230fi.

16. Wichs, W. 1)., KunNeY, F. T., ANd LAE, K.-L. (1969) J. Biol. Chem. 244, 6008.

17. Jost, J.-P., Hsll, A., Hughrs, '. I)., ANb Ryan, L. (1970) J. Biol. Chem. 245, 351.

18. Langax, T. (1969) Proc. Nal. Acad. Sci. ISA $64,1276$.

19. LANGAN, T. (1970) in Role of Cyclic AMP in Cell Function (Greengard, P. and Costa, E., eds.), p. 307, Raven Press, New York.

20. Short, E. C., Warnkr, H. R., ANd Komrner, J. F. (1968) .J. Biol. Chem. 243, 3342.

21. Pogo, A. O., Allprey, V. (i., ind Mirsky, A. F. (1966) Proc. Vat. Acad. Sri. USA 56, 550 .

22. Bonner, J., Dahmus, M. J., Fambrough, D., IIUang, R. C., Marushigr, K., and Tuan, 1). Y. H. (1968) Science 159, 47.

23. Smiti, K. I), Chunch, R. B., and MicCAnтнy, B. J. (1969) Biochemistry 8, 4271

24. Roeder, R. (i., Axi) RuttrR, W. J. (1970) Proc. Nal. Acad. Sci. USA 65, 675.

25. Widslet, C. C., ini Thtı, J. R. (1964) Biochim. Biophys. Acta 87, 531.

26. Pugu, A. E., Littau, V. C., Allerers, V. G., and Mirsky, A. E. (1967) Pror. Nat. Acad. Sci. USA 57, 743 .

27. Rall, T. W., AND R.tTtin, A. (1970) in Role of Cyclic AMP in Cell Function (Greengard, P., and Costa, L., eds.), p. 123, Raven Press, New York.

28. D'Armitinto, H., Johnson, G. A., . Mn Pastan, I. (1972) Proc. Nal. Acad, Sri. USA 69, 459.

29. 1) ARniti, J. L., Ju. (1968) Bacteriol. Rev. 32, 262.

30. Johnson, I. M., And Arlekfy, V. (i. (1972) Arch. Biochem. Biophys. 152, 786.

31. KIsh, V. M., AND Kllinsmith, L. J. (1972) J. Cell Biol. 65, 138a.

32. Kish, V. M., AND KLinsmith, I. J. (1973) f. Biol. Chem., in press.

33. Klyinsmith, L. J., Allfrky, V. (i., AND Mirsky, A. 1. (1966) Science 154, 780.

34. Greshey, F. L., AND Klinsmith, L. J. (1969) Biochim. Biophys. Acta 194, 519.

35. Thng, C. S., Thng, C. T., and Allfrey, V. G. (1971) J. Biol. Chem. 246, 2597.

36. Kamiyama, M., Dastuget, B., ano Kruh, J. 
(1971) Biochem. Biophys. Res. Commun. 44, 1345.

37. SheA, M., and Klizinsmith, L. J. (1973) Biochem. Biophys. Res. Commun. 50, 473.

38. Martelo, O. J., Woo, S. L. C., Reimann,
E. M., AND DAvis, F. W. (1970) Biochemistry 9,4807 .

39. Wicks, W. I). (1971) J. Biol. Chem. 246, 217.

40. I.er, K. L. (1969) Fed, Proc. Fed. Amer. Soc. Exp. Biol. 28, 729 . 